borings proved the Upper Gault to rest on the basal bed of the Sandringham Sands. This points to considerable erosion of the Lower Greensand prior to the deposition of the transgressive clays. At West Dereham and Mouse Hall ("Muzzle "), only a few miles to the north, a thin Iepresentative of the interruptus-zone, not more than 3 feet thick at Mouse Hall, rests directly upon the sandy mammillatus-bed. At both localities we have obtained the typical fossils of these two borizons. At Mouse Hall this remnant of the interruptus-zone is overlain by very pale Upper Gault Clay, which was at one time mistaken for Chalk Marl. This clay yields Inoceramus sulcatus Park. and other fossils of the Upper Gault in its lowest part. It is evident that the base of the overlapping Upper Gault here rests upon a thin remnant of the Lower Gault which has locally not been wholly removed by the etosion accompanying the overlap. These appear to be the most northerly exposures of the Lower Gault known in this country.

North of West Dereham the Upper Gault thins rapidly and becomes highly calcareous. Few good exposures are to be seen until the neighbourhood of Grimston is reached, some 14 miles to the north. Here the characteristic fauna of Bed IX of Folkestone is found a few feet above the base of the overlapping strata, which rest on unfossiliferous Lower Greensand. ${ }^{1}$ At Dersingham the Upper Gault is reduced to 7 feet in thickness and there shows increasing hardness and the introduction of the red coloration which becomes so characteristic at Snettisham and Hunstanton to the north. It becomes evident now that we are dealing with a thin calcareous equivalent of the overlapping argillaceous Upper Gault. The remarkable reduction in the thickness of the Upper Gault may be seen by a comparison of a series of well-sinkings and borings between Stoke Ferry and Snettisham. Within this distance there is a reduction in thickness from 56 feet at Stoke Ferry to $3 \mathrm{ft}$. 6 in. at Snettisham.

(To be continued.)

\title{
The Northward and Eastward Extension of the Karroo Lavas.
}

- By F. P. Menvell, F.G.S., M.I.M.M.

THE lavas which cap the Karroo beds of Southern Africa have general interest as indicating the eruptive activity prevailing at a time of complete quiescence in the European area. The sedimentaries immediately beneath them (Stormberg series) are of Rhætic or even Liassic age, so that the lavas themselves, which are many thousands of feet thick in the Drakensberg range, may confidently be ascribed to the Jurassic period.

I W. Hill \& A. J. Jukes-Browne, "On the Lower Part of the Upper Cretaceous Series in West Suffolk and Norfolk" : Quart. Journ. Geol. Soc., vol. xliii, 1887 , p. 5 s̃ 1 . 
During the last two years the writer has made a number of journeys through Northern Rhodesia and Portuguese East Africa, one of the results of which has been to show that the lavas of this period have an extension considerably further northward and eastward than has been generally recognized. This is not to say that the volcanic rocks themselves have escaped notice-- though even this appears to be the case with the first area to be dealt with--but their age has not been determined. Hence a few notes on the occurrences may not be out of place, though these are necessarily brief, as constant travelling has prevented any detailed petrographical investigation of the features the rocks present.

\section{Northern Area.}

From the railway bridge crossing the Kafue River in Northern Rhodesia, some 250 miles north of the Zambesi bridge at the Victoria Falls, there can be seen almost due east some hills in which the discerning eye will detect distinct indications of a synclinal structure. The only doubts arising as to the reality of this arrangement are due to the fact that the whole area round about is one of Archæan rocks. However, a journey of about 10 miles across the Kafue Flats enables this point to be settled, and the stratified arrangement of the rocks becomes clearer as the hills are approached. It is probable, indeed, that a strip of sediments really underlies the alluvium of the flats almost up the bridge itself, but it is not till in the immediate neighbourhood of the hills that any unmistakeable signs of them are seen, in the shape of a few feet of soft reddish sandstone in the bank of a small stream. It may at once be said, however, that the hills themselves, which are 600 or 700 feet high, are entirely volcanic, and the well-marked step-like appearance they present when seen from the south indicates that they consist of six or seven distinct flows, the number adopted depending on whether the faintly marked ridge stretching out from beneath the last of the much steeper scarps above is basalt or the top of the sandstone, a point which had to be left undecided. Water-level in the Kafue is about 3,200 feet above the sea, so that the tops of the hills must reach to nearly 4,000 feet, the western edge already referred to not being quite the highest point.

An examination of the area showed that the lavas, etc., extend for 10 miles or more east of their first conspicuous outcrops, and probably form a complete basin elongated in that direction. Both north and south they are flanked by much more irregular slopes of the ancient gneisses and schists which emerge from beneath them. Whether there is any faulting round the margins of the younger rocks cannot be definitely decided in the absence of any clear sections of the junction, but though suspicions were entertained that such might be the case, the conclusion was eventually reached, after close investigation, that the base of the sediments rested directly upon the ancient schists and gneisses. These sediments consist of sandstones 
having a total thickness of about 150 feet, of which the uppermost 50 feet are fine and rather crumbly, while the lower 100 feet are harder, more uniform and coarser in grain, and are characterized by the presence of small scattered pebbles. They are, in fact, identical in every respect with the "Escarpment Grits" of the Wankie coalfield further south, and of the intervening areas of Coal Measures, of which the nearest is within about 20 miles. The fact that no more than 50 feet of strata are lithologically similar to the fine-grained Forest Sandstones, which are many hundreds of feet thick elsewhere, is surprising, especially as they rest with apparent conformity on the Escarpment Grits, but it is in line with the remarkable divergences seen among the Karroo strata as they are followed eastward towards the coast.

The lavas, of which the flows, as already noted, average about 100 feet in thickness, are uniformly basalts of the same type as seen at the Victoria Falls. They are highly amygdaloidal at the base and summit of each flow, and the amygdales as usual contain many zeolites. Towards the eastern end of the basin the Kesha River cuts through these rocks at a point where only two flows survive, and its bed is in the Escarpment Grit until it gets on to the gneisses, across which it makes its way into the Kafue, some miles to the north. From the position of the block of basalts, etc., it seems clear that the Kafue has just finished the removal by erosion of a great area of basaltic lavas like those of the Victoria Falls, after first cutting a gorge through them like that of the Zambesi, at the head of which similar falls must at one time have existed. It is also evident that the Kafue, like the Zambesi, had its course largely determined by synclinal structures in the Karroo rocks. Although the Karroo rocks are often much faulted, the faulting has had no direct bearing on the position of these rivers; indeed, not far away, at the Kariba Gorge, the Zambesi is in the ancient gneisses and schists, on the upthrow side of a series of seven step faults which successively bring up the Archæan rocks against the Karroo strata. It is hoped to describe the structure of this interesting area at a subsequent date.

\section{Eastern Areas.}

I. Tete.-The presence of Coal Measures (i.e. Lower Karroo beds) at Tete, on the Zambesi, in Portuguese East Africa, has long been known, and igneous rocks have been recorded from the same area. It is quite possible that the occurrence of the lavas has also been recorded, though $I$ have not seen any distinct reference to them myself, the volcanics to which reference is generally made being the dolerite intrusions which are extremely numerous in the Tete district. This latter fact is remarkable, as in Northern and Southern Rhodesia no dyke traversing the Karroo strata has yet been definitely identified. The lavas to which I refer are situated a few miles above the Lupata Gorge, and must be clearly distinguished from the volcanic rocks of the gorge itself. The Karroo lavas are, as usual, 
basalts and are probably anything from 500 to 1,000 feet in thickness. They have a gentle easterly dip, and the directly underlying rocks are very badly exposed; in fact, the sandstones seen to the west are on a horizon which is probably at least 500 or 600 feet below the base of the flows. They are riearly white felspathic grits, extremely similar to the Upper Sandstones of the Wankie Coalfield in Southern Rhodesia, but they clearly belong to a higher stratigraphical horizon, as they are certainly 1,000 feet above the Coal Shales. Above the basalts are sandstones of an entirely different character, very like some of the New Red rocks in England. They are no doubt of Jurassic age, and are about 1,200 feet thick, being succeeded by the Lupata Volcanics, which must be of Lower Cretaceous age, if, indeed, they do not reach down into the Jurassic period. It should be noted that the isolated sheet of columnar rhyolite which caps the magnificent scarp at the entrance to the gorge divides the sandstones almost equally into two divisions. These may be termed the Upper and Lower Lupata Sandstones for convenient reference. They are very varied in character, ranging from coarse conglomeratic varieties to what may be termed "marls", but are chiefly coarse to medium sandstones red, purple, brown, yellow, or even occasionally white in colour. The Lupata Volcanics are entirely different from any of the Karroo lavas. As a field term "felsparporphyry " may be applied to most of the varieties, but some of the rocks are rhyolitic, while others contain large porphyritic nepheline crystals (often represented on weathered surfaces by cavities), and at two localities specimens were secured which contain numerous porphyritic crystals which must be leucite or psendomorphs after that mineral. Tuffs and agglomerates oceur at intervals and also seams of tufaceous sandstone. The volcanics are overlain by the Cretaceous sandstones, which often show pebbles of the characteristic Lupata Volcanics, and are themselves succeeded on. the Sheringoma plateau by limestones containing numerous fossils which range from Late Tertiary to Upper Cretaceous age. The thickness of all these strata is very great, and it is hoped to describe them in more detail when the petrographical and palæontological collections are worked up. They are referred to chiefly to emphasize the fact that to attribute all the nepheline-bearing rocks of East Africa to the Tertiary period is clearly erroneous, as the Lupata Voleanics cannot by any possibility be higher up in the stratigraphical scale than Lower Cretaceous. No faulting can be invoked to invalidate the stratigraphical evidence, owing to the fortunate fact that, as already mentioned, the overlying Cretaceous rocks contain pebbles derived from the volcanics adjacent to them.

II. Maringwe Area.- If the inland district of Maringwe be approached from the north side, i.e. from the Zambesi, or from the east, as, for instance, from Inyaminga, the gently inclined Cretaceous sandstones of Sena in the one case, or the Tertiary limestones in the other, are gradually found to give way to older and older sediments 
until near the Barue border a series of basaltic lavas are met with emerging from beneath them. Messrs. Teale and Wilson long ago referred to these, but though they do not definitely correlate them with the Lupata Volcanics, they were evidently disposed to do so. As a matter of fact, the Lupata Volcanics die out in a most remarkable way only about 20 miles south of the Zambesi, as indicated by the disappearance of the marked feature they make when looking across country. Their position is, however, clearly indicated in the course of the traverses referred to by the sudden disappearance of the pebbles derived from them, which are very conspicuous in the Cretaceous beds, but are, of course, absent from the Lupata sandstones. An extensive area of these is crossed before reaching the basalts, which emerge from beneath them with a gentle easterly dip, a fact which places their age beyond question and is entirely confirmed by their lithological character, even though they are of more varied types than usual. They form a belt about 7 or 8 miles across, partly flat country, but their western edge rises into a scarp several hundred feet in height, breached by several rivers, of which the Hata affords a particularly good section. The number of flows is evidently considerable and the thickness of the series greater than at Tete, while much more variety is seen in the colour, texture, etc., of the lavas. There are masses and beds of agglomerate at several points ; some of the former no doubt indicate vents. The volcanics must stretch a hundred miles from north to south; their southern termination appears to be near the great mountain mass of Gorongoza, and northward they may even connect with those of the Tete area. Inside the Barue boundary the underlying sandstones are well seen, an interesting point, as they are completely obscured by alluvium near the Lupata Gorge. They are very varied in character, a common type being arkose-like, with pink felspars. - A single narrow band is fine-grained, and pale-buff in colour; this is the only stratum seen at all reminiscent of the Forest Sandstones of Rhodesia. A feature of the locality is the large number of dolerite dykes by which the sandstones are intersected and the remarkable metamorphism of the latter in their vicinity. These are frequently converted into rocks indistinguishable in the field from a pinkish granite, for which they were indeed mistaken until clearly seen in situ.

\title{
On Lower Lias Ammonites from Skye.
}

\author{
By Dr. L. F. Spath.
}

THE writer has thought it desirable, in the following observations, 1 to embody the results of his examination, last September, of the Arnioceras-bearing beds of Ardnish, near Broadford in Skye. The strata yielded a number of Ammonites of the Upper Coroniceras, gmuendensis, and Atomoceras subzones, and belong chiefly to the "Shaly Beds" of division iv of the Broadford Beds of the Survey 